\title{
Recent developments in Quaternary dating methods
}

\author{
Irka Hajdas, Susan Ivy-Ochs, Zürich, Robyn Picker- \\ ing, Frank Preusser, Bern
}

\section{Introduction}

Determining numerical ages for artefacts, sediments and biological remains is a major aspect of Quaternary research. Both accurate and precise numerical ages are important as, in contrast to older geological periods, the Quaternary comprises of a very short period of time (2.6 Million years). Over such a brief time, species evolution is generally too small to allow for biostratigraphy establishment as a ubiquitous tool for correlation. This is particularly pertinent as the time spans of interest are often relatively short on a geological scale: often a few hundred years or less. Furthermore, continental deposits are of particular interest in Quaternary research, perhaps more so than in most fields of classical geology. Firstly, a major focus of Quaternary research is on the human genetic and cultural evolution, as well as our ancestor's interaction with climate and environment. Findings related to human activity are, however, mainly restricted to continental settings. Secondly, Quaternary topics, such as palaeoclimate and palaeoseismic research, are often carried out in the context of past and potential future hazards for mankind, hence, in areas that are or have been populated. Most continental records are, due to their sedimentary nature, fragmentary and bear only rarely fossil remains that fulfil the necessary requirements of biostratigraphic markers. Secure correlation of different findings is thus often possible by direct numerical dating only.

Quaternary geochronology was established with the advent of radiocarbon in the 1950's and several other methods have been developed since then. Methodological developments have been rapid, especially during the past two decades. It is the aim of this article to give a brief overview of the most relevant of those methods available in the context of continental Quaternary research (Table 1). Its purpose is to introduce the non-specialist to potential methods and their limitations with regard to establishing chronologies for continental records. A much more detailed summary is provided by a series of recently published review papers edited by PREUSSER et al. (2008).

\section{Brief overview of different methods}

\subsection{Radiocarbon}

The cosmogenic radioactive isotope of carbon $\left({ }^{14} \mathrm{C}\right.$ or radiocarbon) is produced in the atmosphere, quickly oxidized to $\mathrm{CO}$ and $\mathrm{CO}_{2}$ and well mixed within the atmosphere. The constant exchange between the atmosphere and other carbon reservoirs builds the basis of the ${ }^{14} \mathrm{C}$ dating method. Living organisms (biota) incorporate the ${ }^{14} \mathrm{C}$ during photosynthesis (plants) or via the food chain (animals). Equilibrium between input and decay of ${ }^{14} \mathrm{C}$ exists in the living tissue. The cutoff of ${ }^{14} \mathrm{C}$ uptake (death or deposition of the inorganic carbon) marks the time zero of the radiocarbon clock and ${ }^{14} \mathrm{C}$ activity measured in the material is used to calculate the time that elapsed since that event. The half-life of $5730 \pm 40 \mathrm{yr}$ sets the limit of the ${ }^{14} \mathrm{C}$ dating method when approaching ages older than $50000 \mathrm{BP}$ Calculation of the radiocarbon ages requires information about initial ${ }^{14} \mathrm{C}$ content at the time of deposition or death. Due to the temporal variability of the atmospheric ${ }^{14} \mathrm{C}$ content (effects of variable production rates and exchange rates in global carbon reservoirs) this value is only assumed to be constant; it must later be corrected in a calibration process that is using an experimentally constructed calibration curve (radiocarbon ages or activities in the past are placed on the calendar time scale). Calibration of radiocarbon ages is a mathematical procedure, applied in calibration programs, that finds the calendar ages corresponding to the measured ${ }^{14} \mathrm{C}$ age. Dependent on the nature of the calibration curve this may result in a wide range of calendar ages and/or multiple intervals, thus reflecting another limitation of the ${ }^{14} \mathrm{C}$ method.

Nearly sixty years after first radiocarbon ages were published radiocarbon dating is still a dynamic field with a wide range of applications mainly in geochronology but also in environmental and biomedical studies. Recent advances in sample preparation and measurements techniques allow new applications and much higher through-put of samples measured. These developments lead to higher resolution chronologies of records, providing the option for dating various fractions of carbon in studied material, which allows better understanding of contamination problem. Examples, which are of direct interest to Quaternary studies of the last 50000 years, include new methods of preparation bones or treatment of wood and charcoal samples (HAJdAs et al. 2007, and references therein). The advance in preparation techniques helps to reduce the contamination of sample with modern or old carbon that could interfere with measurement of the correct ${ }^{14} \mathrm{C}$ activity remaining in a dated sample.

The changes in the atmospheric content of ${ }^{14} \mathrm{C}$ have been reconstructed back to 26000 years, however the need for a reliable calibration curve covering the 


\begin{tabular}{|c|c|c|c|c|}
\hline Method & Suitable material & Event dated & Minimum age & Maximum age \\
\hline Radiocarbon & Organic matter, inorganic carbon & $\begin{array}{l}\text { Death of organism, } \\
\text { formation of } \\
\text { carbonate }\end{array}$ & $\begin{array}{l}\text { 1. Positive }{ }^{14} \mathrm{C} \\
\text { ages before } \\
1950 \mathrm{AD} \\
\text { 2. Negative }{ }^{14} \mathrm{C} \\
\text { ages after } 1950 \\
\text { AD* }\end{array}$ & ca. 50000 years \\
\hline $\begin{array}{l}\text { Cosmogenic } \\
\text { nuclides }\end{array}$ & $\begin{array}{l}\text { Quartz }\left({ }^{10} \mathrm{Be},{ }^{14} \mathrm{C},{ }^{21} \mathrm{Ne},{ }^{26} \mathrm{Al}\right) \\
\text { Olivine, pyroxene }\left({ }^{3} \mathrm{He},{ }^{21} \mathrm{Ne}\right) \\
\text { Whole rock silicates or carbonates } \\
\left({ }^{36} \mathrm{Cl}\right)\end{array}$ & $\begin{array}{l}\text { Exposure of rock } \\
\text { surface, (burial) }\end{array}$ & $\begin{array}{l}\text { Hundreds of } \\
\text { years }\end{array}$ & Millions of years \\
\hline Uranium series & Carbonates & $\begin{array}{l}\text { Formation of } \\
\text { carbonate }\end{array}$ & $\begin{array}{l}\text { Few thousand } \\
\text { years }\end{array}$ & ca. 500000 years \\
\hline Luminescence & $\begin{array}{l}\text { Quartz or feldspar in sediments, } \\
\text { artefacts or rocks }\end{array}$ & $\begin{array}{l}\text { Last daylight } \\
\text { exposure, last } \\
\text { heating, mineral } \\
\text { formation }\end{array}$ & $\begin{array}{l}\text { Down to some } \\
\text { years }\end{array}$ & $\begin{array}{l}\text { Up to some hundred } \\
\text { thousand years }\end{array}$ \\
\hline ESR & Carbonates, teeth, (quartz) & $\begin{array}{l}\text { Mineral formation, } \\
\text { (heating, last } \\
\text { daylight exposure) }\end{array}$ & $\begin{array}{l}\text { Down to some } \\
\text { decades }\end{array}$ & $\begin{array}{l}\text { Up to one million years } \\
\text { (and beyond?) }\end{array}$ \\
\hline
\end{tabular}

* In some cases dating possible using the «bomb peak»

Table 1: Overview of the dating methods described in this article Überblick über die in diesem Artikel beschriebenen Datierungsmethoden Vue d'ensemble des méthodes de datation décrites dans cet article

last 50,000 years cannot be overestimated. Numerous studies have focussed on the development and the extension of the radiocarbon calibration curve. Figure 1 shows the present INTCAL04 calibration curve (REIMER et al. 2004). The tree ring based chronology is constantly pushed back in time beyond the Holocene into the Late Glacial. Records such as trees, lake sediments, deep sea sediments, corals and stalagmites have to be dated by other than radiocarbon dating methods. As a consequence of a growing interest in the calibration of very old radiocarbon ages $(20000$ to 50000 BP) (RAMSEY et al. 2006) the future update of the INTCAL04 data set will provide an estimated calibration curve for the last 50000 to 55000 years.

\subsection{Uranium series}

The Uranium and Thorium decay series contain radioactive isotopes of many elements, among them $\mathrm{U}, \mathrm{Th}, \mathrm{Pa}$ and $\mathrm{Ra}$, and end in stable $\mathrm{Pb}$. In a closed system the intermediate isotopes exist in so-called secular equilibrium, that is, their abundance ratios are such that each isotope decays at exactly the rate at which it is produced. Various natural processes cause the fractionation of these elements, disturbing these equilibria among isotopes. The gradual return to equilibrium conditions allows for a quantification of the time passed since the fractionation causing event. In the case of U-Th dating, Th is separated from parent $U$ due to the vast difference in the solubility between these elements in water. Thus, calcite precipitates with negligible amounts of Th. The subsequent in situ decay of ${ }^{234} \mathrm{U}$ to ${ }^{230} \mathrm{Th}$ can be used to date material by measuring the present levels of both isotopes by mass spectrometry (BouRdon et al. 2003). Uranium series has been shown to be a precise dating tool on both marine (coral) and terrestrial (stalagmites, flowstones, tufa) carbonates dating back to 500000 years before present (EDWARDs et al. 1987). U-Th dating has been critical in palaeoclimate studies as it can provide ages for past sea level high stands from corals. High resolution records of terrestrial climate change recorded in stalagmites are greatly enhanced by the ease of U-Th dating of such material. 


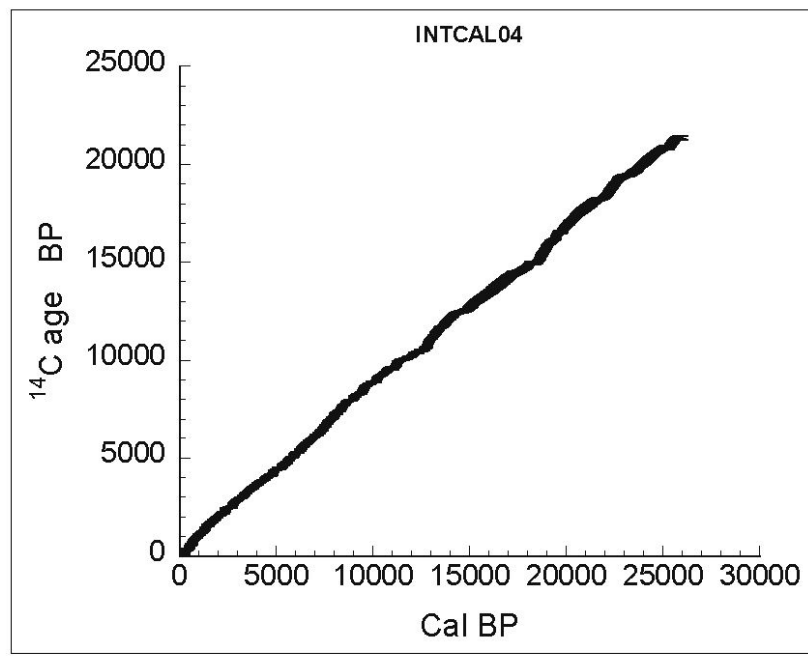

Fig. 1: Calibration curve based on the INTCAL04 data set (REIMER et al. 2004)

Tree-ring data sets built 12400 years of the calibration curve. The extension back to $26000 \mathrm{cal} \mathrm{BP}$ is based on marine data sets with site-specific reservoir corrections.

Kalibrierungskurve, basierend auf dem INTCALO4Datensatz (REIMER et al. 2004)

Courbe de calibrage basée sur les données INTCAL04 (REImer et al. 2004)

Material as young as a few thousand years can be dated (СовB et al. 2003). Beyond 500000 years equilibrium between $\mathrm{Th}$ and $\mathrm{U}$ is re-established, defining the upper limit of the technique. With advances in mass spectrometry corals as old as 600000 years can be dated (ANDERSEN et al. 2008). U-Pb dating is possible on older material, and while research is ongoing, this remains rather experimental. Another aspect of on going research is the U-Th dating of material which does not behave as a closed system, such as fossil bones and teeth; this is complex as uranium and thorium isotopes are mobile and their uptake and loss needs to be modelled (see Pike \& Pettitt 2003 for more).

\subsection{Cosmogenic nuclides}

Cosmogenic nuclides $\left({ }^{3} \mathrm{He},{ }^{10} \mathrm{Be},{ }^{14} \mathrm{C},{ }^{21} \mathrm{Ne},{ }^{26} \mathrm{Al},{ }^{36} \mathrm{Cl}\right)$ are produced in exposed minerals in rock surfaces and sediment due to interactions with secondary cosmic ray particles. The length of time that a rock surface has been exposed can be determined by measuring the concentrations of these nuclides (Gosse \& Phillips 2001). ${ }^{10} \mathrm{Be},{ }^{14} \mathrm{C},{ }^{21} \mathrm{Ne}$, and ${ }^{26} \mathrm{Al}$ are measured in quartz, ${ }^{3} \mathrm{He}$ and ${ }^{21} \mathrm{Ne}$ in olivine and pyroxene, while ${ }^{36} \mathrm{Cl}$ is measured in whole rock samples of any rock type. An amazing array of landforms can be surface exposure dated with cosmogenic nuclides making them an indispensable tool in geomorphology. In addition to the determination of exposure ages of boulders on moraines and landslide deposits, which in many cases can be dated by no other method, innovative ongoing and future studies include the dating of terraces using depth profiling, elucidation of differential rates of bedrock erosion under past glaciers and the dating of deeply buried sediments with multiple cosmogenic nuclides (burial dating). Surface exposure dating relies heavily on detailed field mapping and careful observation during sample selection. Focus is on rock surfaces that are the most representative of the age of the landform and the least affected by post-depositional disturbances. Difficulties such as rock surface weathering, post-depositional boulder instability or pre-exposure, nevertheless, must always be kept in mind. Data interpretation is made in light of regional morphostratigraphy and results from other dating methods for the same or related sites.

With respect to methodology, reduction of backgrounds reflecting improvements in both sample preparation procedures and measurement techniques (accelerator mass spectrometry) allows the dating of rock surfaces that have been exposed for only a few hundred years, for example those created during historical events (such as landsliding or glacier advance). At the other end of the spectrum, in slowly weathering environments exposure ages up to many millions of years are measured (SchaEFer et al. 1999). In the Alpine realm obtaining exposure ages older than several hundred thousand years is unlikely (Ivy-OCHs et al. 2007). The limit is given by the rate of rock surface weathering, which is several $\mathrm{mm} / \mathrm{ka}$ in the Alps. Geomorphologists await the addition of ${ }^{14} \mathrm{C}$ measured in quartz to the set of available cosmogenic nuclides, which will prove especially useful for young and/or rapidly weathering landforms.

\subsection{Luminescence}

This method utilizes a signal in natural minerals such as quartz and feldspar that is sensitive to heat and light. The luminescence signal used for dating originates from the interaction of naturally occurring radioactivity with the crystal lattice of minerals (cf. AITKEN 1998). Radiation energy is stored within the lattice during burial and is erased once the mineral is exposed to certain stimulation energy. The event being dated is i) mineralisation, ii) last heating to ca. $450^{\circ} \mathrm{C}$, or iii) last daylight exposure of the mineral grains. Thus, luminescence dating can be used in the context of archaeological (e.g. ceramics, heated stones) as well as geoscientific research (e.g. sediments, volcanic xenoliths). Currently, luminescence comprises several stimulation techniques such as thermoluminescence (TL), optically stimulated luminescence (OSL), infrared stimulated luminescence (IRSL) and infrared stimulated radiofluorescence (IR-RF), all of which are 
related but have different physical properties. Comparing ages derived by the different techniques can be used to cross-check the reliability of the results.

Problems associated with luminescence dating arise from incomplete zeroing of the luminescence signal during the resetting event (e.g. daylight exposure), changes in sediment radioactivity caused by radioactive disequilibrium (e.g. in some carbonate or organicrich sediments), changes in sediment moisture and instability of the latent luminescence signal, in particular in a variety of feldspars. The dating range is high depending on the properties of the material being investigated, in particular the amount of radioactivity within the sediment, and the potential of minerals to store the radiation damage.

While a decade ago these problems left the reliability of some dating results rather questionable, the performance of luminescence dating has significantly improved during the last decade with the introduction of new measurement techniques (single grain laser-stimulation) as well as improvements in measurement protocols (single-aliquot regenerative-dose) Recent work is focusing on how to further improve the accuracy as well as the reproducibility of luminescence dating (Wintle \& Murray 2006), exploring the possibility to date difficult material such a proglacial sediments (Duller 2006; Preusser et al. 2007) and the potential to extend the dating range down to several hundred-thousand years (RHoDEs et al. 2006) as well as dating deposits as young as some decades or even years (MADSEN et al. 2007).

\subsection{Electron spin resonance (ESR)}

The origin of the ESR signal is similar to luminescence and both methods are partially closely related with regard to methodology. The major differences are the approach to signal stimulation (in ESR a magnetic field is being used) and the material being investigated. Most applications of ESR have been either carbonates such as corals and molluscs (ScHELLMANN et al. 2008) or tooth enamel (GRÜN 2006). The event being dated is the formation of the mineral. With these materials, up-take and loss of radioactive elements, in particular from the Uranium decay chain, and re-crystallisation from aragonite to calcite are specific problems. Recent research has also been focussing on dating quartz, especially to use the light-sensitive part of the ESR signal in a similar way as is used in luminescence dating. First results look promising but it may need a few more years before all methodological problems are fully explored; the method should be hence considered as still in an experimental stage. Despite all limitations, a variety of papers have reported a good consistency of ESR ages for the different materials mentioned above with independent age control. If the problems are carefully addressed the method allows dating from a few hundred (or even less) to several hundred-thousand years, and possibly even beyond one million years.

\section{Conclusions}

The progress in dating methods during the past two decades has significantly improved the possibility to constrain the timing of geological processes, climate, environmental change and human evolution during the Quaternary. Due to the availability of modern dating approaches parts of Quaternary history have had to be re-written and we now have a much better understanding of the interaction of environment, climate and humans in the past. Nevertheless, all of the methods mentioned here still have potential for improvement with regard to precision, accuracy, age range and materials suitable for dating and these are presently being explored.

\section{References}

AtTken, M.J. (1998): An introduction to optical dating. - Oxford: University Press.

Andersen, M.B., Stirling, C.H., Potter, E., Halliday, A.N., Blake, S.G., McCulloch, M.T., Ayling, B.F. \& M. O'LeARY (2008): High-precision U-series measurements of more than 500,000 year old fossil corals. - In: Earth and Planetary Science Letters 265: 229-245.

Bourdon, B., Turner, S., Henderson, G.M. \& C.C. LUNDSTROM (2003): Introduction of U-series geochemistry. - In: Reviews in Mineralogy and Geochemistry 52: 1019.

Cobb, K.M., Charles, C.D., Cheng, H., Kastner, M. \& R.L. EDWARDS (2003): U-Th-dating of living and young fossil corals from the cntral tropical Pacific. - In: Earth and Planetary Science Letters 210: 91-103.

Duller, G.A.T (2006): Single grain optical dating of glacigenic deposits. - In: Quaternary Geochronology 1:296-304

Edwards, R.L., Chen, J.H. \& G.J. Wasserburg (1987): ${ }^{238} \mathrm{U}-{ }^{234} \mathrm{U}-{ }^{230} \mathrm{Th}-{ }^{232} \mathrm{Th}$ systematics and the precise measurement of time over the past 500,000 years. - In Earth and Planetary Science Letters 81: 175-192.

Gosse, J.C. \& F.M. Phillips (2001): Terrestrial in situ cosmogenic nuclides: theory and application. - In: Quaternary Science Reviews 20: 1475-1560.

GRÜN, R. (2006): Direct dating of human fossils. - In: Yearbook of Physical Anthropology 49: 2-48.

Hajdas, I., Bonani, G., Furrer, H., Mäder, A. \& W. SсHосн (2007): Radiocarbon chronology of the mammoth site at Niederweningen, Switzerland: Results from dating bones, teeth, wood, and peat. - In: Quaternary International 164-165: 98-105.

Ivy-Ochs, S., Kerschner, H. \& C. SCHLÜChter (2007) 
Cosmogenic nuclides and the dating of Lateglacial and early Holocene glacier variations: The Alpine perspective. - In: Quaternary International 164-165: 53-63. Madsen, A.T., Muray, A.S., Andersen, T.J. \& M. PEJRUP (2007): Optical dating of young tidal sediments in the Danish Wadden Sea. - In: Quaternary Geochronology 2: 89-94.

Pike, A.W.G \& P.B. Pettitt (2003): U-series dating and human evolution. - In: Bourdon, B., Turner, S., Henderson, G.M. \& C.C. Lundstrom: Introduction of U-series geochemistry. - In: Reviews in Mineralogy and Geochemistry 52:607-630.

Preusser, F., Blei, A., Graf, H. \& C. Schlüchter (2007): Luminescence dating of Würmian (Weichselian) proglacial sediments from Switzerland: Methodological aspects and stratigraphical conclusions. - In: Boreas 36, 130-142.

Preusser, F., Hajdas, I. \& S. Ivy-Ochs (eds) (2008): Recent developments in Quaternary dating methods. - = Quaternary Science Journal (Eiszeitalter \& Gegenwart) 57.

Ramsey, C.B., Buck, C.E., Manning, S.W., Reimer, P. $\&$ H. van der Plicht (2006): Developments in radiocarbon calibration for archaeology. - In: Antiquity 80: 783-798.

Reimer, P.J., Baillie, M.G.L., Bard, E., Bayliss, A., Beck, J.W., Bertrand, C.J.H., Blackwell, P.G. \& C.E. Buck (2004): IntCal04 Terrestrial Radiocarbon Age Calibration, 0-26 Cal Kyr BP. - In: Radiocarbon 46: 1029-1058.

Rhodes, E.J., Singarayer, J.S., Raynal, J.-P., WestaWay, K.E. \& F.Z. SBiHI-Alaoui (2006): New age estimates for the Palaeolithic succession of Casablanca, Morocco. - In: Quaternary Science Reviews 25: 25692585.

Schäfer, J., Ivy-OChs, S., Wieler, R., Leya, I., BAUR, H., SChlüChteR, C. \& G.H. Denton (1999): Cosmogenic noble gas studies in the oldest landscape on earth: Surface exposure ages of the Dry Valleys, Antarctica. - In: Earth and Planetary Science Letters 167: 215-226.

Schellmann, G., Beerten, K. \& U. Radtke (2008): Electron spin resonance (ESR) dating of Quaternary materials. - In: Quaternary Science Journal (Eiszeitalter \& Gegenwart) 57:150-178.

Wintle, A.G. \& A.S. Murray (2006): A review of quartz optically stimulated luminescence characteristics and their relevance in single-aliquot regeneration dating protocols. - In: Radiation Measurements 41: 369-391.

\section{Abstract: Recent developments in Quaternary dating methods}

An overview of methods to numerically date continental Quaternary deposits is provided including radiocarbon, Uranium series, cosmogenic nuclides, luminescence and electron spin resonance. Physical background and methodology are briefly described and potential problems as well as recent developments in the field are highlighted.

Keywords: Quaternary, geochronology, dating

\section{Zusammenfassung: Aktuelle Entwicklungen in Datierungsmethoden des Quartärs}

Ein Überblick über Methoden numerischer Altersbestimmungen für kontinentale Quartärablagerungen wird vorgestellt. Hierin enthalten sind Radiokohlenstoff, Uranserien, kosmogene Nuklide, Lumineszenz und Elektronen-Spin-Resonanz. Die physikalischen Grundlagen und methodische Aspekte werden kurz beschrieben, und potentielle Probleme sowie gegenwärtige Entwicklungen werden aufgezeigt.

Schlüsselwörter: Quartär, Geochronologie, Datierung

\section{Résumé: Développements récents des méthodes de calibrage du Quaternaire}

Une vue d'ensemble des méthodes permettant de dater numériquement des dépôts continentaux quaternaires est présentée. Les techniques suivantes sont traitées: le radiocarbone, les séries d'uranium, les nuclides cosmogéniques, la luminescence et la résonance de spin électronique. La base physique et la méthodologie sont brièvement décrites avant d'aborder les problèmes potentiels ainsi que les développements récents dans ce domaine.

Mots-clés: Quaternaire, géochronologie, datation

Dr. Irka Hajdas, Ion Beam Physics, Paul Scherrer Institute, CH-5232 Villigen PSI, and Swiss Federal Institute of Technology Zurich, Schafmattstrasse 20, CH-8093 Zürich, Switzerland

e-mail: hajdas@phys.ethz.ch

Dr. Susan Ivy-Ochs, Ion Beam Physics, Paul Scherrer Institute, CH-5232 Villigen PSI, Swiss Federal Institute of Technology Zurich, Schafmattstrasse 20, CH-8093 Zürich, and Department of Geography, University of Zurich, Winterthurerstrasse 190, CH-8057 Zürich, Switzerland

e-mail:ivy@phys.ethz.ch

M.Sc. Robyn Pickering, PD Dr. Frank Preusser, Institut für Geologie, Universität Bern, Baltzerstrasse 1+3, CH-3012 Bern, Switzerland.

e-mail: robyn@geo.unibe.ch

e-mail:preusser@geo.unibe.ch

Manuskripteingang/received/manuscrit entré le 5.5.2008

Annahme zum Druck/accepted for publication/accepté pour limpression: 12.9.2008 